\title{
MICROSTRUCTURE AND PROPERTIES OF NANO-FIBROUS PCL- $b$-PLLA SCAFFOLDS FOR CARTILAGE TISSUE ENGINEERING
}

\author{
Liumin $\mathrm{He}^{1,2,4 \dagger}$, Bin $\mathrm{Liu}^{3 \dagger}$, Guan Xipeng ${ }^{1,2}$, Gaoyi Xie ${ }^{1,2}$, Susan Liao ${ }^{4}$, Daping Quan ${ }^{1,2 *}$, Daozhang Cai ${ }^{3}$, Jiang Lu ${ }^{1,2}$, \\ and S. Ramakrishna ${ }^{4}$
}
${ }^{1}$ DSAPM Lab, School of Chemistry and Chemical Engineering, Sun Yat-Sen University, Guangzhou, 510275, China. ${ }^{2}$ PCFM Lab, OFCM Institute, Sun Yat-Sen University, Guangzhou, 510275, China.
${ }^{3}$ Department of Orthopedics, Third Affiliated Hospital, Sun Yat-sen University, Guangzhou 510630, China ${ }^{4}$ Nanoscience and Nanotechnology Initiative, National University of Singapore, 9 Engineering Drive 1, Singapore 117576, Singapore
${ }^{\dagger}$ These authors contributed equally to this work.

\begin{abstract}
Nano-fibrous scaffolds which could potentially mimic the architecture of extracellular matrix (ECM) have been considered a good candidate matrix for cell delivery in tissue engineering applications. In the present study, a semicrystalline diblock copolymer, poly( $\varepsilon$-caprolactone)block-poly(L-lactide) (PCL-b-PLLA), was synthesized and utilized to fabricate nano-fibrous scaffolds via a thermally induced phase separation process. Uniform nano-fibrous networks were created by quenching a PCL- $b$-PLLA/THF homogenous solution to $-20^{\circ} \mathrm{C}$ or below, followed by further gelation for 2 hours due to the presence of PLLA and PCL microcrystals. However, knot-like structures as well as continuously smooth pellicles appeared among the nanofibrous network with increasing gelation temperature. DSC analysis indicated that the crystallization of PCL segments was interrupted by rigid PLLA segments, resulting in an amorphous phase at high gelation temperatures. Combining TIPS (thermally induced phase separation) with saltleaching methods, nano-fibrous architecture and interconnected pore structures $(144 \pm 36 \mu \mathrm{m}$ in diameter) with a high porosity were created for in vitro culture of chondrocytes. Specific surface area and protein adsorption on the surface of the nano-fibrous scaffold were three times higher than on the surface of the solid-walled scaffold. Chondrocytes cultured on the nano-fibrous scaffold exhibited a spherical condrocyte-like phenotype and secreted more cartilage-like extracellular matrix (ECM) than those cultured on the solid-walled scaffold. Moreover, the protein and DNA contents of cells cultured on the nanofibrous scaffold were 1.2-1.4 times higher than those on the solid-walled scaffold. Higher expression levels of collagen II and aggrecan mRNA were induced on the nanofibrous scaffold compared to on the solid-walled scaffold. These findings demonstrated that scaffolds with a nanofibrous architecture could serve as superior scaffolds for cartilage tissue engineering.
\end{abstract}

Keywords: Cartilage, tissue engineering, PCL- $b$-PLLA, thermally induced phase separation, nanofibrous scaffold.

\author{
*Address for correspondence: \\ Daping Quan \\ School of Chemistry and Chemical Engineering, \\ Sun Yat-sen University, \\ Guangzhou 510275, China
}

Telephone Number: +862084114030

FAX Number: +862084112245

E-mail: cesqdp@mail.sysu.edu.cn

\section{Introduction}

Cartilage defects resulting from aging and joint injury usually cause joint pain and loss of mobility. However, cartilage repair and regeneration are major challenges despite recent progress in orthopedic surgery, because the lesions do not spontaneously heal and their consequences have a significant social and economic impact (Brooks et al., 2002; Sellards et al., 2002). The tissue engineering strategy provides a promising therapy to repair cartilage defects and restore joint functions (Stoddart et al., 2009; Ochi et al., 2001; Cancedda et al., 2003; Tuli et al., 2003). A three-dimensional (3D) scaffold is employed for delivery or recruitment of reparative cells in an organized manner to bridge voids within cartilage defects, offering considerable promise as repair strategies (Solchaga et al., 2001; Grande et al., 1999). Thus, 3D biodegradable synthetic polymeric systems play a critical role in tissue engineering. The nature of scaffold and the physicochemical properties of the material are critical parameters for tissue formation (Chen et al., 2002).

Polyhydroxyacids, such as polylactide (PLA), polyglycolide (PGA), poly( $\varepsilon$-caprolactone) (PCL) and their copolymers poly(lactide-co-glycolide) (PLGA), poly(lactide-co-caprolactone) (PLC), poly(glycolide-cocaprolactone) (PGC), have been extensively used in tissue engineering due to their advantages of wide availability, ease of processing, adjustable degradation and mechanical properties, and low inflammatory response (Nair et al., 2007). These polymers were also applied in cartilage tissue engineering, and were documented to support the attachment and proliferation of primary animal chondrocytes (Chu et al., 1995; Gugala et al., 2000; Freed et al., 1994). However, PLA, PGA and PLGA suffer from the disadvantages of rigidity which limited their application as tissue-engineered cartilage ( Grad et al., 2003). PCL is in a rubbery state at room temperature due to a low $T_{\mathrm{g}}$ (glass transition temperature) and suffers a very slow degradation in vivo. Therefore, PLC or PGC might be promising materials for cartilage reconstruction because the incorporation of PCL could enhance the flexibility of the scaffold, and the degradation could be 

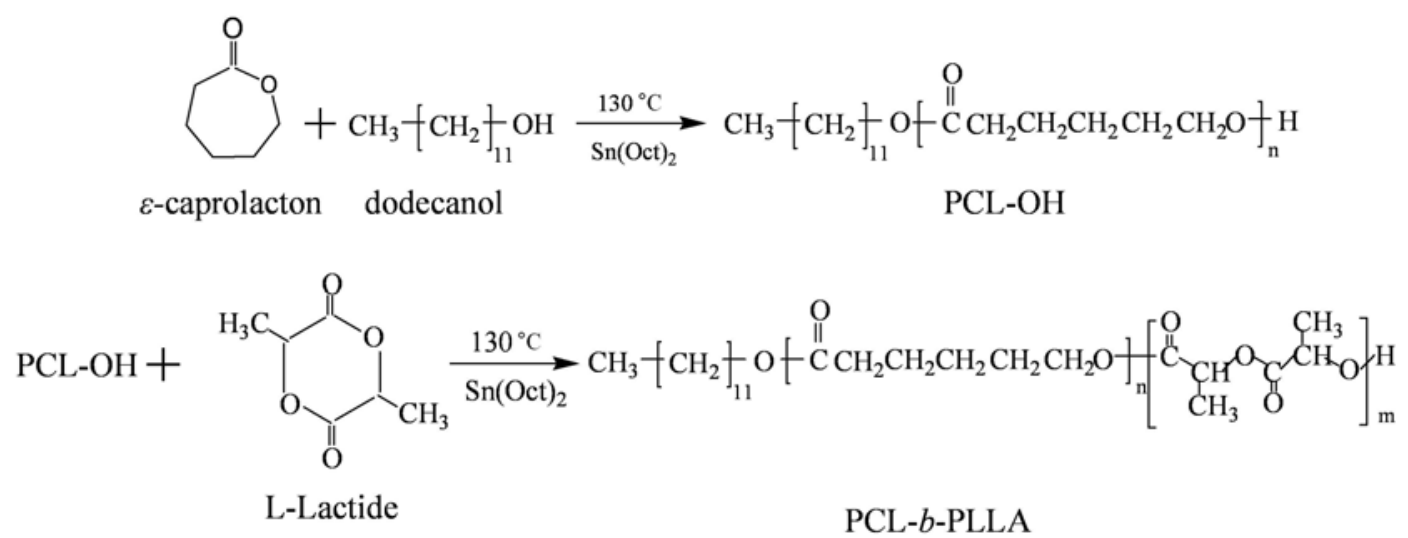

Figure 1. Schematic illustration of the synthesis of PCL- $b$-PLLA.

modulated by changing the composition of the copolymer (Jeong et al., 2004; Zhao et al., 2007; Kister et al., 2000; Li et al., 1996). It was also documented that biodegradable polyurethanes based on the PCL and PLLA segments were alternative candidates for cartilage tissue engineering, and that they were degraded to nontoxic by-products in vivo (Gorna et al., 2006).

Recently, intensive studies showed that cells recognized nanometric topologies of fibrous or microporous structure (Laurencin et al., 1999). Such a nanoscale structure, which geometrically mimicked the native state of the extracellular matrix (ECM), could selectively enhance protein adsorption and consequentially enhance cell attachment (Woo et al., 2003), and it therefore received much academic attention in medical applications (Ma, 2008). Zhang and Ma pioneered the preparation of PLLA nano-fibrous scaffolds with a fiber diameter ranging from 50 to $500 \mathrm{~nm}$ through thermally induced liquid-liquid phase separation (L-L TIPS) (Ma and Zhang, 1999). In a study by Hu et al., MC-4 cells acquired a more rounded shape on a PLLA nano-fibrous matrix with abundant interactions with nanofibers. No long dense stress fibers or typical focal adhesion structures were formed on the nano-fibrous matrix (Hu et al., 2008). Moreover, the nano-fibrous architecture of PLLA enhanced the osteogenic differentiation and mineralization of embryonic stem cells compared to the solid-walled architecture in both two and three dimensional cultures (Smith et al., 2009). In this regard, the nano-fibrous architecture may provide an environment closer to the ECM than the solid-walled architecture. Due to the mechanism of nanofiber fabrication by TIPS, semicrystalline homopolymers or copolymers which would crystallize and form microcrystalline domains during the TIPS process, were indispensable. PLLA/PCL blends were also utilized to prepare $3 \mathrm{D}$ nano-fibrous scaffolds by L-L TIPS from a THF solution (Zhao et al., 2004). However, PLLA with a high molecular weight could usually not be mixed with PCL, and the adhesion between PCL and PLLA became weak, resulting in poor mechanical properties (Kim et al., 2001).

In view of the facts above, we designed and synthesized a semicrystalline biblock copolymer, poly( $\varepsilon$-caprolactone)block-poly(L-lactide) (PCL- $b$-PLLA). Both the PCL and the PLLA segments have the capability of crystallization, thus the nano-fibrous structure could be probably prepared by TIPS. For an ideal scaffold for cartilage tissue engineering, an interconnected pore network is a prerequisite to load cells and facilitate tissue ingrowth (Buma et al., 2004). Klompmaker's studies revealed that implants with macropore sizes of at least 100-300 $\mu \mathrm{m}$ allowed fibrocartilage formation in the implant (Klompmaker et al., 1992; Klompmaker et al., 1993). Consequently, combining TIPS with the salt-leaching method, a high porosity with an interconnected pore structure $(144 \pm 36 \mu \mathrm{m})$ and nano-fibrous architectures were created from PCL- $b$-PLLA copolymer for in vitro culture of chondrocytes.

\section{Materials and Methods}

\section{Materials}

$\varepsilon$-Caprolactone ( $\varepsilon$-CL, 99\%, Aldrich, St. Louis, MO, USA) was distilled from $\mathrm{CaH}_{2}$ in vacuum under dry $\mathrm{N}_{2}$. L-Lactide (Purac Biochem, Gorinchem, the Netherlands) was purified by recrystallization from ethyl acetate twice, and dried in vacuum at room temperature. All reagents were used without further purification.

\section{Synthesis and characterization of polymers}

PCL- $b$-PLLA $\left(W_{\text {PCL }} / W_{\text {PLLA }}=50 / 50\right)$ block copolymer was synthesized according to Fig. 1. Firstly, PCL pre-polymer (PCL-OH) with a pre-designed molecular weight of $5.0 \times 10^{4}$ was polymerized in bulk with $\mathrm{Sn}(\mathrm{Oct})_{2}$ as catalyzer and dodecanol as initiator at $130^{\circ} \mathrm{C}$ under vacuum for 30 $\mathrm{h}$. The ring-opening polymerization of L-LA with the predesigned molecular weight of $5.0 \times 10^{4}$ was then carried out at $130^{\circ} \mathrm{C}$ under vacuum for $30 \mathrm{~h}$, using PCL-OH as macromolecular initiator and $\mathrm{Sn}(\mathrm{Oct})_{2}$ as catalyzer. All crude products were purified by dissolution-precipitation in chloroform/alcohol.

PLLA homopolymer with a molecular weight of $5.0 \times 10^{4}$ was obtained via polymerization of L-LA using $\mathrm{Sn}(\mathrm{Oct})_{2}$ as catalyzer and dodecenol as initiator for $30 \mathrm{~h}$ at $130^{\circ} \mathrm{C}$ under vacuum. 
The structure of polymers was confirmed by ${ }^{1} \mathrm{H}$ NMR and ${ }^{13} \mathrm{C}$ NMR performing on a Mercury-Plus 300 spectrometer (Varian, Inc., Pala Alto, CA, USA), using $\mathrm{CDCl}_{3}$ as solvent. IR spectra were recorded on a Fourier transform infrared (FTIR) spectrometer (Nexus 670, Nicolet, GMI, Ramsey, MN, USA).

The molecular weight and its distribution were determined at $30^{\circ} \mathrm{C}$ by a gel permeation chromatography (GPC) system consisting of a Waters 1525 binary high pressure liquid chromatography (HPLC) pump, three ultrastyragel columns, and a Waters 2414 refractive index detector (Waters Alliance GPC2000, Waters Corporation, Milford, MA, USA).

\section{Fabrication of nano-fibrous scaffolds}

The nano-fibrous scaffold was fabricated by liquid-liquid phase separation from the solution of PCL- $b$-PLLA in tetrahydrofuran (THF). Briefly, a $5 \%(w / v)$ clear solution was obtained by dissolving a certain mount of PCL- $b$ PLLA into THF at $50^{\circ} \mathrm{C}$. Then $3 \mathrm{~mL}$ of polymer solution was quickly poured into a $25 \mathrm{~mL}$ glass beaker followed by quenching to a chosen temperature $\left(-40^{\circ} \mathrm{C},-20^{\circ} \mathrm{C}, 4^{\circ} \mathrm{C}, 8^{\circ} \mathrm{C}\right.$, $12^{\circ} \mathrm{C}, 16^{\circ} \mathrm{C}$ ) and maintained for $2 \mathrm{~h}$. Soon during this period, the solution became a gel. After that, the gel was immersed into $4{ }^{\circ} \mathrm{C}$ double-distilled water for 2 days to leach out the solvent by changing the water four times per day. The scaffold was obtained after lyophilization under $0.940 \mathrm{mbar}$ at $0^{\circ} \mathrm{C}$ for five days (ALPHA2-4 freeze dryer, Martin Christ Gefriertrocknungsanlagen Gmbh, Osterode am Harz, Germany).

PLLA nano-fibrous scaffolds were also prepared by phase separation adopting the same steps above. The chosen $T_{\text {gel }}$ was $4^{\circ} \mathrm{C}, 8^{\circ} \mathrm{C}, 12^{\circ} \mathrm{C}$ and $16^{\circ} \mathrm{C}$.

To prepare a macroporous scaffold, $\mathrm{NH}_{4} \mathrm{HCO}_{3}$ particles $(125-200 \mu \mathrm{m})$ that were 5 times heavier than the copolymer were added to the $5 \%(w / v)$ polymer solution in THF, and followed by the same procedures as mentioned above. The scaffold was referred as nano-fibrous scaffold (NF scaffold). Solid-walled scaffold (SW scaffold) was fabricated as control by solid-liquid (S-L) phase separation from 5\% $(w / v)$ PCL- $b$-PLLA/dioxane solution. In this approach, the weight ratio of $\mathrm{NH}_{4} \mathrm{HCO}_{3}$ particles to polymer was still 5:1 $(w / v)$, and the temperature of S-L phase separation was $-40^{\circ} \mathrm{C}$. All samples were dried through lyophilization under $0.940 \mathrm{mbar}$ at $0^{\circ} \mathrm{C}$ for five days, and the $\mathrm{NH}_{4} \mathrm{HCO}_{3}$ particles were removed by leaching in double- distilled water. The scaffold was finally obtained by lyophilization.

\section{Characterization of PCL- $b$-PLLA scaffolds}

The morphology of scaffolds was observed by scanning electron microscopy (SEM) in a JSM-6380LA Analytical Scanning Electron Microscope (JEOL Ltd., Tokyo, Japan).

Thermal properties were analyzed with a Differential Scanning Calorimeter (MDSC2910: TA Instruments, Wilmington, DE, USA) in a temperature range from $20^{\circ} \mathrm{C}$ to $220^{\circ} \mathrm{C}$ with a heating rate of $10^{\circ} \mathrm{C} / \mathrm{min}$. The first heating was performed for the analysis.

Porosity of PCL- $b$-PLLA macroporous scaffolds was measured by a gravimetric method. Dry samples were weighed, and their weight was denoted $m_{\text {dry }}$. The samples were filled with ethanol under vacuum, and subsequently weighed, and their weight was denoted $m_{\text {wet }}$. The volume of pores, $V_{\text {pore }}$, was calculated according to Eq. (1):

$$
V_{\text {pore }}=\left(m_{\text {wet }}-m_{\text {dry }}\right) / \rho_{\text {ethanol }}
$$

where $\rho_{\text {ethanol }}$ was the density of ethanol which was $0.789 \mathrm{~g} /$ $\mathrm{cm}^{3}$.

The volume of the whole scaffold was measured as the volume of double-distilled water $\left(V_{\text {scaffold }}\right)$ by immersing the scaffold in water, assuming that the amount of water absorbed in the scaffold was negligible during the short time of the experiment. Therefore the porosity of scaffold was calculated as the quotient of the volume of pores and the total volume of the scaffold according to Eq. (2). Five measurements were carried out for each sample and the results were expressed as mean \pm standard deviation (SD).

$$
\text { Porosity }=V_{\text {pore }} / V_{\text {scaffold }}
$$

The nitrogen $\left(\mathrm{N}_{2}, 99.99 \%\right)$ adsorption measurement at $77 \mathrm{~K}$ was conducted using a porosimetry analyzer (ASAP 2020, Micromeritics, Norcross, GA, USA). The specific surface area was calculated from the Brunauer-Emmett-Teller (BET) plot of the $\mathrm{N}_{2}$ adsorption isotherm.

The mechanical properties of the macroporous PCL$b$-PLLA (50/50) scaffold were tested using a universal mechanical properties tester (Instron 3345, Norwood, MA, USA) with a $100 \mathrm{~N}$ load-cell at a compression speed of $1 \mathrm{~mm} / \mathrm{min}$. A cylindrical specimen with a diameter of $10 \mathrm{~mm}$ and a length of $5 \mathrm{~mm}$ was used. Fully dried samples were compressed between parallel plates at $25^{\circ} \mathrm{C}$ and $70 \%$ humidity.

\section{Protein adsorption to scaffolds}

Nano-fibrous-walled and solid-walled PCL- $b$-PLLA (50/ 50) macroporous scaffolds of equal weight were first wetted by soaking in ethanol for an hour and subsequently in phosphate buffered saline (PBS) for 30 min thrice. The scaffolds were then incubated in PBS overnight at room temperature. The wetted scaffolds were incubated in $0.5 \%$ $(w / v)$ bovine serum albumin (Shanghai Bo'ao Biological Technology Co., Ltd. Shanghai, China) solutions in PBS for $4 \mathrm{~h}$. After the incubation, the scaffolds were removed from the protein solution and then washed in PBS thrice $(1 \times 1 \mathrm{~h})$ to remove free and loosely adsorbed proteins. The total amount of protein adsorbed to the scaffolds was measured using the MicroBCA assay (Pierce, Rockford, IL, USA) and was calculated from the standard curve of BSA.

\section{Chondrocyte isolation and culture}

Fresh chondrocytes were isolated from 3 separate articular cartilages harvested from the knee joint of a 1-year-old dog. Circa $1 \mathrm{~mm}^{3}$ pieces of fresh canine articular cartilage were digested in $0.25 \%$ trypsin $(2 \mathrm{~mL} / \mathrm{g}$ tissue) for $1 \mathrm{~h}$ at $37^{\circ} \mathrm{C}$, followed by $0.2 \%$ type II collagenase for $16 \mathrm{~h}$ at $37^{\circ} \mathrm{C}$. Digested suspension was filtered through a $100-\mathrm{mm}$ mesh nylon filter and washed 2 times in PBS supplemented 
with penicillin $(100 \mathrm{U} / \mathrm{mL})$ and streptomycin $(100 \mathrm{mg} / \mathrm{mL})$. Chondrocytes were seeded at an initial density of $3.5 \times 10^{4}$ cells $/ \mathrm{cm}^{2}$ at each passage in Dulbecco's modified Eagle's Medium (DMEM) containing $4.5 \mathrm{mg} / \mathrm{mL} \mathrm{D}$-glucose, $0.1 \mathrm{mM}$ nonessential amino acids, $1 \mathrm{mM}$ sodium pyruvate, $100 \mathrm{mM}$ HEPES buffer, $100 \mathrm{U} / \mathrm{mL}$ penicillin, $100 \mathrm{mg} / \mathrm{ml}$ streptomycin and $0.29 \mathrm{mg} / \mathrm{mL}$ L-glutamate and supplemented with $10 \%$ of fetal bovine serum at $37^{\circ} \mathrm{C}$ with $5 \% \mathrm{CO}_{2}$ in $\mathrm{T}-25$ flasks. Culture medium was changed every 3 days. Cells were passaged with trypsin/EDTA $(0.25 \%$ / $0.1 \mathrm{mM})$.

\section{SEM observation of cell morphology in scaffolds}

The NF and SW scaffolds were sterilized with $75 \%$ alcohol for $24 \mathrm{~h}$ and then washed in PBS for three times. Chondrocytes of passage 3 were seeded on the scaffolds of $6 \mathrm{~mm}$ in diameter and $2 \mathrm{~mm}$ in height (SW scaffold and NF scaffold) at a density of $1 \times 10^{5}$ cells/scaffold in a 48 well plate. At culture time points of $12 \mathrm{~h}$, day 1 and day 6 , the scaffolds were washed once with PBS, and then fixed with $2.5 \%$ glutaraldehyde fixative and osmium tetroxide at $4^{\circ} \mathrm{C}$ for $2 \mathrm{~h}$ each. After dehydration with a series of graded alcohols, the cells kept in a fume hood for air-drying. The scaffold was then gold-sputtered in vacuum and examined by SEM.

\section{Protein content measurements}

Chondrocytes were seeded at a density of $2 \times 10^{6}$ cells/ scaffold in a 48 -well plate on the PCL- $b$-PLLA macroporous scaffolds (SW scaffold and NF scaffold). At culture time points of day 3, day 6 and day 12, the composites were lysed by RIPA (Radio Immunoprecipitation Assay) Lysis Buffer (150mM NaCl, $0.1 \%$ SDS, $1 \%$ sodium deoxycholate, $1 \%$ triton $\mathrm{X}-100$, $50 \mathrm{mM}$ Tris- $\mathrm{HCl}$ (pH 7.5), 2mM EDTA) (Biocolor BioScience\&Technology Co., Shanghai, China) on ice for 30 minutes. The suspension was centrifuged in the refrigerated microcentrifuge at maximum speed for $10 \mathrm{~min}$ and the supernatants were harvested. The content of protein was determined by $\mathrm{BCA}^{\mathrm{TM}}$ protein assay kit (Pierce) $0.1 \mathrm{~mL}$ sample was mixed with $2.0 \mathrm{~mL}$ work reagent and incubated at $37^{\circ} \mathrm{C}$ for 30 minutes. Then absorbance measurements were taken at $562 \mathrm{~nm}$ after the samples were cooled to room temperature (FLUO star OPTIMA; BMG Labtech, Offenburg, Germany). The protein content was calculated from the standard curve of BSA.

\section{DNA content measurements}

Chondrocytes were seeded at a density of $2 \times 10^{6}$ cells/ scaffold in 48-well plate on the PCL- $b$-PLLA macroporous scaffolds (SW scaffold and NF scaffold). At culture time points of day 3 , day 6 and day 12, the composites were digested overnight at $60^{\circ} \mathrm{C}$ in a solution of proteinase $\mathrm{K}$ $(0.5 \mathrm{mg} / \mathrm{mL})$. The $100 \mu \mathrm{L}$ of lysate was mixed with $1 \mathrm{ml}$ of Hoechst 33258 (Sigma, St Louis, MO, USA) working solution $(0.1 \mu \mathrm{g} / \mathrm{ml})$ in TEN $\left(10 \mathrm{mM}\right.$ Tris, $1 \mathrm{mM} \mathrm{Na}_{2}$ EDTA, $0.1 \mathrm{M} \mathrm{NaCl}, \mathrm{pH} 7.4)$. Fluorescence was measured at excitation (EX) 365 and emission (EM) 458nm in the fluorometer. The DNA content was calculated from the standard curve of DNA from calf thymus (Sigma).

\section{Gene expression analysis for Collagen type II and aggrecan}

Chondrocytes were seeded at a density of $2 \times 10^{6}$ cells/ scaffold in a 48 -well plate on the PCL- $b$-PLLA macroporous scaffolds (SW scaffold and NF scaffold). At day 3, day 6 and day 12, the collagen type II and aggrecan gene was assessed by RT-PCR (Reverse transcription polymerase chain reaction). Briefly, total RNA was extracted from cells using the RNeasy Mini RNA isolation kit (Qiagen, Crawley, UK). The cDNA was reverse transcribed from $1 \mu \mathrm{g}$ of total cellular RNA using ThermoScript RT-PCR system (Invitrogen, Carlsbad, CA, USA). The amplification primer pair for collagen type II was selected as 52 - CGA GGT GAC AAA GGA GAA GC -32 † and 52- GTC TCC GCT CTT CCA TTC AG -32, aggrecan was 52- TGG AGC AAC TGA CTC CAG TG 32 †and 52- GGA CGC TAG TGC TGA TGA CA-32. PCR reactions were performed using aliquots of the $\mathrm{cDNA}$ template with Platinum PCR Supermix kit (Invitrogen). Pre-denaturation was $94^{\circ} \mathrm{C}$ for $5 \mathrm{~min}$; The cDNA was amplified by 30 cycles of denaturation $\left(40 \mathrm{~s}\right.$ at $\left.94^{\circ} \mathrm{C}\right)$, annealing (collagen II $40 \mathrm{~s}$ at $60^{\circ} \mathrm{C}$, aggrecan $40 \mathrm{~s}$ at $60^{\circ} \mathrm{C}$ ), and elongation $\left(60 \mathrm{~s}\right.$ at $\left.72^{\circ} \mathrm{C}\right)$, followed by a final step at $72^{\circ} \mathrm{C}$ for $10 \mathrm{~min}$. PCR products were separated electrophoretically on a $2.0 \%$ agarose gel (Sigma) and the products were visualized by staining in ethidium bromide (Invitrogen).

\section{Statistics}

All data presented are expressed as mean \pm standard deviation (SD). Statistical comparisons were carried out using analysis of variance (ANOVA, SAS Institute, Cary, NC). A value of $p<0.05$ was considered to be statistically significant. Each parameter was conducted with three samples $(n=3)$ unless noted.

\section{Results}

\section{Synthesis of PCL-b-PLLA copolymer}

PCL- $b$-PLLA block copolymer was synthesized in two steps. Firstly, hydroxyl-terminated PCL (PCL-OH) prepolymer was synthesized as shown in Fig. 1, and its structure was confirmed by ${ }^{1} \mathrm{H}$ NMR in Fig. 2(A). The molecular weight of PCL-OH was calculated from the integrals of the characteristic peaks at $2.3 \mathrm{ppm}$ and $0.87 \mathrm{ppm}$ (Guan et al., 2007). When ring-opening polymerization of L-LA was carried out using the macromolecular monomer PCL-OH as initiator, new signals attributed to the PLLA segment at 5.16ppm and $1.60 \mathrm{ppm}$ were detected in Fig. 2B. The resulting molar ratio and the molecular weight of block copolymer determined by ${ }^{1} \mathrm{H}$ NMR were listed in Table 1. The resulting molar ratio of PCL segment to PLLA segment in copolymer was close to the feed molar ratios. The copolymer had one glass transition temperature and two melting point attributed to PCL and PLLA segment respectively.

In order to prove that the synthetized copolymer was block copolymer rather than random copolymer, ${ }^{13} \mathrm{C} \mathrm{NMR}$ and FTIR were used to confirm its structure. As shown in 
Table 1. Synthesis results for PCL- $b$-PLLA (50/50)

\begin{tabular}{ccccccccc}
\hline Polymer & CL/L-LA Molar & CL/L-LA Molar & $M_{\mathrm{n}, \mathrm{NMR}}$ & $M_{\mathrm{n}, \mathrm{GPC}}$ & $M_{w}, M_{n,}$ & $T_{g} /{ }^{\circ} \mathrm{C}$ & $T_{c} /{ }^{\circ} \mathrm{C}$ & $T_{m} /{ }^{\circ} \mathrm{C}$ \\
& Feed Ratio & Resultant Ratio & $\times 10^{4}$ & $\times 10^{4}$ & ${ }^{G P C}$ & & & \\
\hline PCL-OH & - & - & $6.20^{\mathrm{a}}$ & - & - & -65.5 & - & 65.6 \\
PCL- $b$-PLLA & 1.26 & 1.44 & $11.60^{\mathrm{b}}$ & 9.0 & 1.22 & -59.7 & ${ }^{c} 29.3{ }^{\mathrm{d}} 118.2$ & ${ }^{\mathrm{e}} 57.1 / /^{\mathrm{f}} 177.6$ \\
PLLA & - & - & 4.80 & 5.0 & 1.12 & 60.8 & - & 177.2 \\
\hline
\end{tabular}

a Determined by ${ }^{1} \mathrm{H}$ NMR: $M_{\mathrm{n}, \mathrm{PCL}-\mathrm{OH}}=I_{\delta=2.3} / I_{\delta=0.87} \times 114 \times 1.5+114+185$

${ }^{\mathrm{b}}$ Determined by ${ }^{1} \mathrm{H}$ NMR: $M_{\mathrm{n}, \mathrm{PCL}-\mathrm{b} \text {-PLLA }}=M_{\mathrm{n}, \mathrm{PCL}-\mathrm{OH}}+I_{\delta=5.16} / I_{\delta=4.05} \times 2 \times 72 \times \mathrm{n}_{\mathrm{PCL}}, \mathrm{n}_{\mathrm{PCL}}$ was

the number of repeating segments in PCL-OH

${ }^{c}$ the crystallization temperature of PCL segment

d the crystallization temperature of PLLA segment

${ }^{e}$ the peak melting temperature of PCL segment

$\mathrm{f}$ the peak melting temperature of PLLA segment

Table 2. Thermal properties of PCL- $b$-PLLA (50/50) scaffolds prepared at different $T_{\text {gel }}$ s.

\begin{tabular}{ccccccc}
\hline $\begin{array}{c}T_{g e l} \\
\left({ }^{\circ} \mathrm{C}\right)\end{array}$ & $\begin{array}{r}{ }^{a} T_{\text {im }} \cdot P C L \\
\left({ }^{\circ} \mathrm{C}\right)\end{array}$ & $\begin{array}{c}{ }^{b} T_{p m \cdot P C L} \\
\left({ }^{\circ} \mathrm{C}\right)\end{array}$ & $\begin{array}{c}\Delta H_{m \cdot P C L} \\
(\mathrm{~J} / \mathrm{g})\end{array}$ & $\begin{array}{c}{ }^{\mathrm{a}} T_{i m \cdot P L L A} \\
\left({ }^{\circ} \mathrm{C}\right)\end{array}$ & $\begin{array}{c}{ }^{b} T_{p m \cdot P L L A} \\
\left({ }^{\circ} \mathrm{C}\right)\end{array}$ & $\begin{array}{c}\Delta H_{m \cdot P L L A} \\
(\mathrm{~J} / \mathrm{g})\end{array}$ \\
\hline$-40{ }^{\circ} \mathrm{C}$ & 50.1 & 63.1 & 40.8 & 164.1 & 177.2 & 27.5 \\
$-20{ }^{\circ} \mathrm{C}$ & 52.4 & 63.6 & 39.5 & 163.9 & 178.0 & 29.0 \\
$4{ }^{\circ} \mathrm{C}$ & 51.9 & 63.5 & 26.7 & 163.0 & 176.2 & 26.3 \\
$8{ }^{\circ} \mathrm{C}$ & 46.7 & 62.6 & 29.5 & 163.7 & 175.4 & 28.2 \\
$12{ }^{\circ} \mathrm{C}$ & 46.0 & 61.3 & 24.5 & 165.0 & 176.3 & 28.1 \\
$16{ }^{\circ} \mathrm{C}$ & 44.6 & 62.5 & 25.2 & 163.4 & 176.4 & 33.5 \\
\hline
\end{tabular}

${ }^{a}$ the initial melting temperature

${ }^{b}$ the peak melting temperature

Table 3. Properties of macroporous PCL- $b$-PLLA (50/50) scaffolds fabricated with different wall structures. $p<0.05$, $\mathrm{n}=3$.

\begin{tabular}{cccccc}
\hline sample & porosity & pore size $(\mu \mathrm{m})$ & $\begin{array}{c}\text { Specific surface } \\
\left(\mathrm{m}^{2} / \mathrm{g}\right)\end{array}$ & $\begin{array}{c}\text { Amount of protein } \\
\text { adsorbed }(\mu \mathrm{g})\end{array}$ & $\begin{array}{c}\text { Compression } \\
\text { modulus }(\mathrm{kPa})\end{array}$ \\
\hline PCL- $b$-PLLA SW scaffold & $95.5 \% \pm 1.5 \%$ & ${ }^{\mathrm{a}} 168 \pm 69 /^{\mathrm{b}} 40 \pm 15$ & $2.90 \pm 0.45$ & $249 \pm 43$ & $90 \pm 15$ \\
PCL- $b$-PLLA NF scaffold & $93.0 \% \pm 1.0 \%$ & $144 \pm 36$ & $8.09 \pm 0.23$ & $808 \pm 67$ & $108 \pm 20$ \\
\hline
\end{tabular}

${ }^{a}$ The diameter of the macropores created by the porogen.

${ }^{b}$ The diameter of micropores created by evaporation of solvent. 


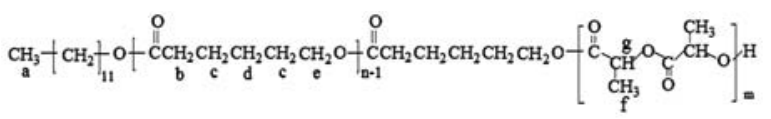
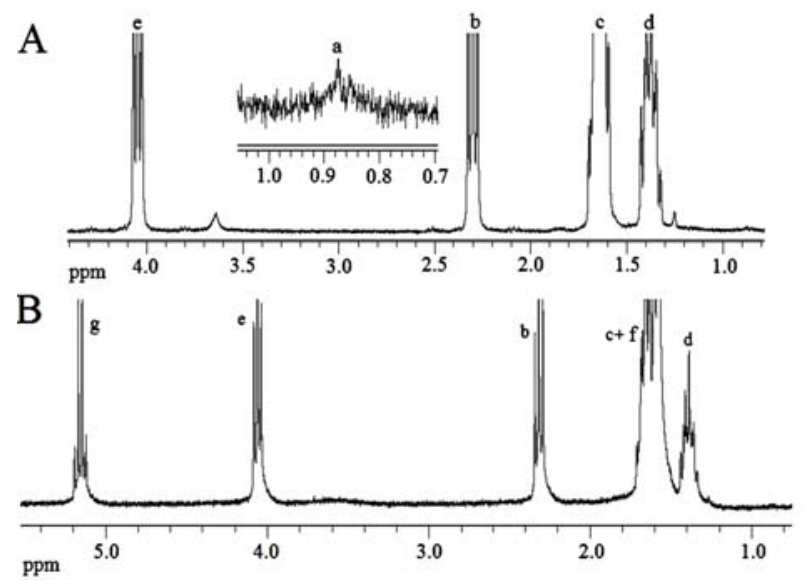

Figure 2. ${ }^{1} \mathrm{H}$ NMR spectra of PCL-OH (A) and PCL$b$-PLLA (B) at $298 \mathrm{~K}$ in $\mathrm{CDCl}_{3}$.

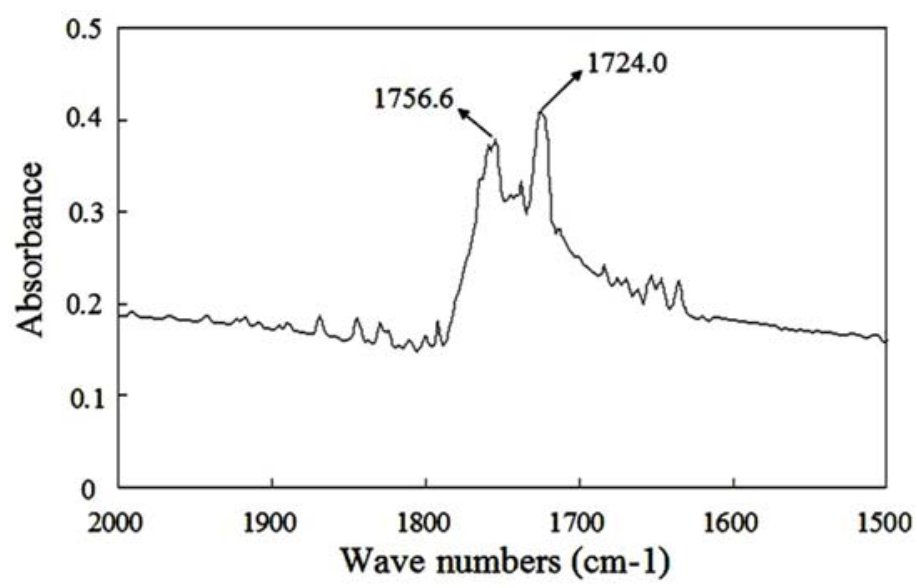

Figure 4. FTIR spectrum of PCL- $b$-PLLA diblock copolymer. The two absorptions at $1757 \mathrm{~cm}-1$ and $1724 \mathrm{~cm}-1$ corresponded to the stretching vibration of ester carbonyl groups for PCL and PLLA blocks.
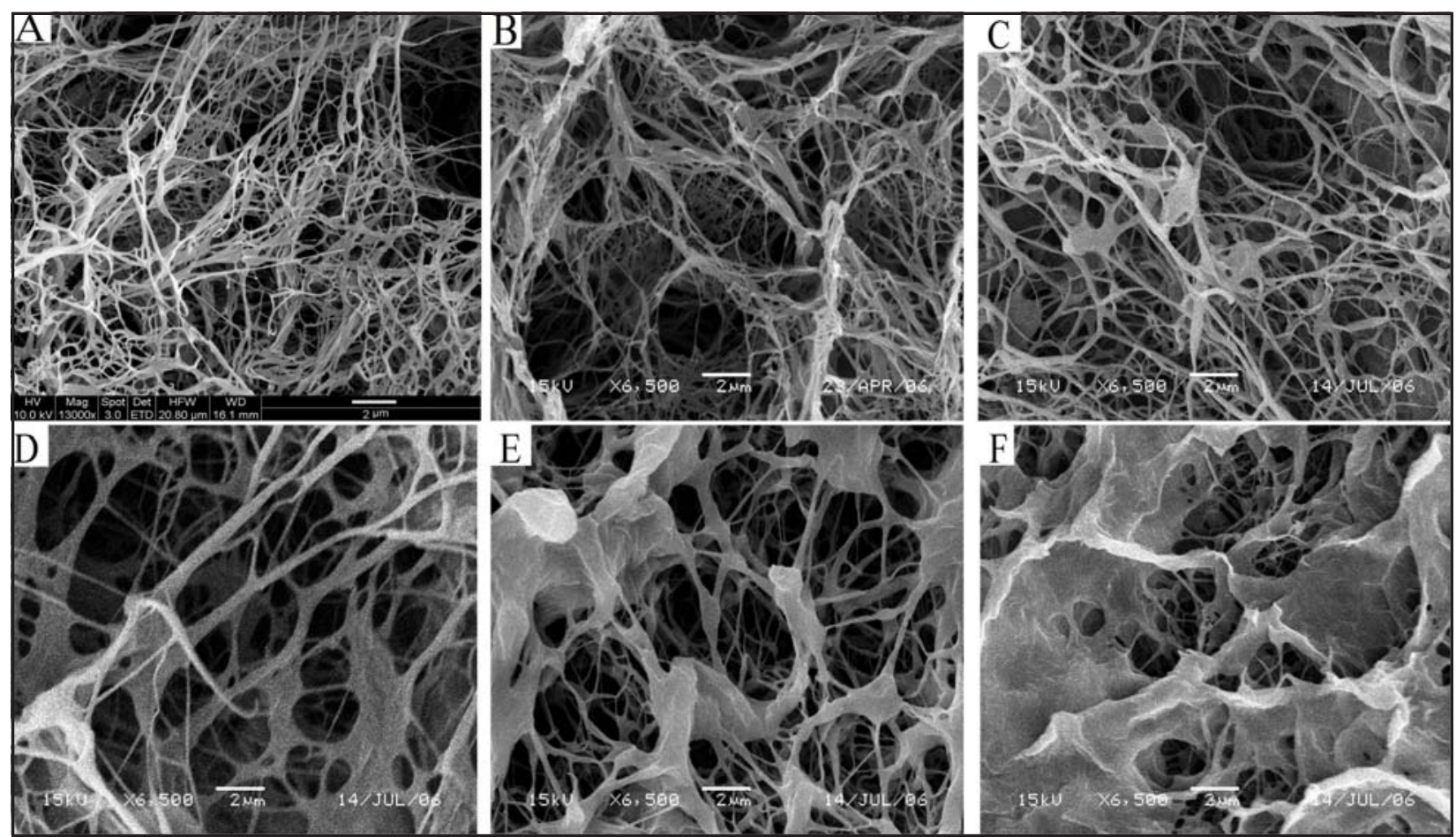

Figure 5. SEM pictures of PCL- $b$-PLLA (50/50) nano-scaffolds fabricated from a solution of 5.0\% $(w / v)$ in THF at different $T_{\text {gel }} \mathrm{s}$ : (A) $-40^{\circ} \mathrm{C}$; (B) $-20^{\circ} \mathrm{C}$; (C) $4{ }^{\circ} \mathrm{C}$; (D) $8^{\circ} \mathrm{C}$; (E) $12^{\circ} \mathrm{C}$ and (F) $16^{\circ} \mathrm{C}$. 

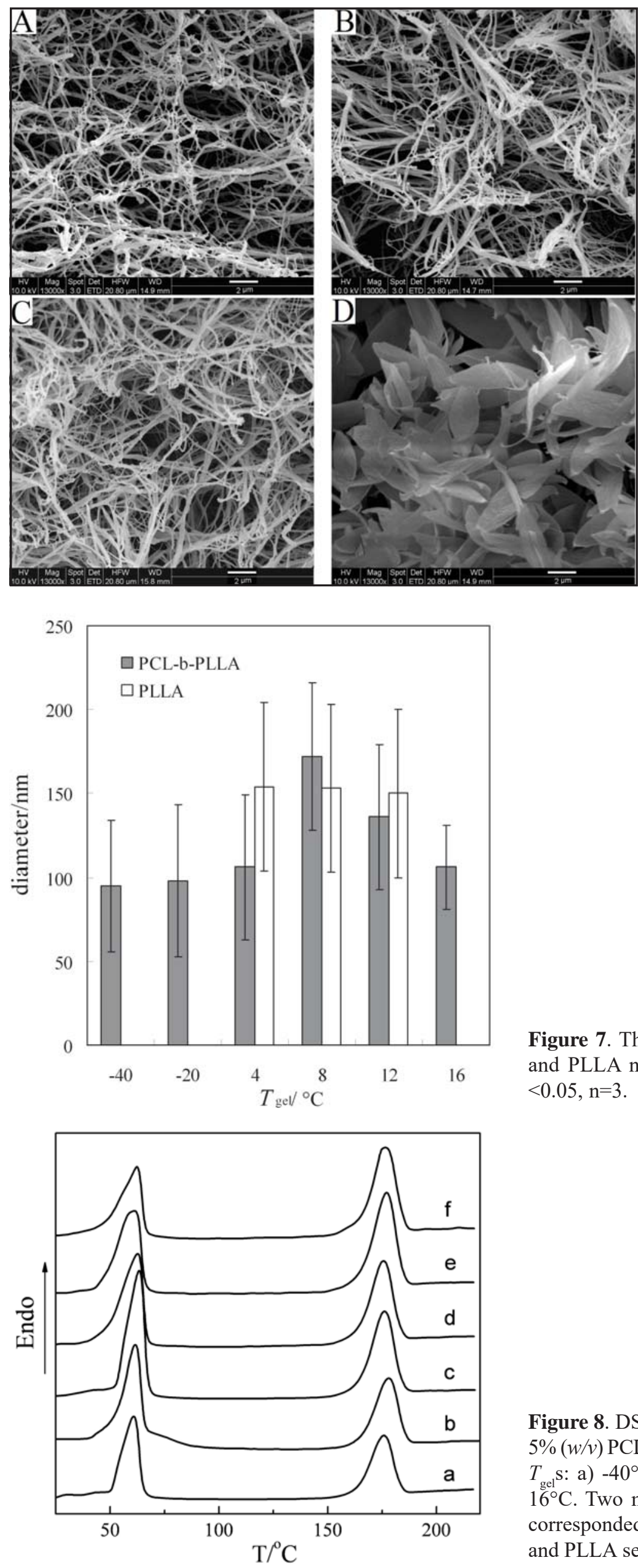

Figure 6. SEM pictures of PLLA nanoscaffolds fabricated from a solution of $5.0 \%(w / v)$ in THF at different $T_{\text {gel }} \mathrm{s}:(\mathrm{A})$ $4^{\circ} \mathrm{C}$; (B) $8^{\circ} \mathrm{C}$; (C) $12^{\circ} \mathrm{C}$ and (D) $16^{\circ} \mathrm{C}$.
Figure 7. The fiber diameter of PCL- $b$-PLLA (50/50) and PLLA nano-fibrous scaffolds at different $T_{\text {gel }}$ s. $p$ $<0.05, \mathrm{n}=3$.
Figure 8. DSC thermogram of scaffolds prepared from $5 \%(w / v)$ PCL- $b$-PLLA (50/50)/THF solution at different $T_{\text {gel }}$ s: a) $-40^{\circ} \mathrm{C}$; b) $-20^{\circ} \mathrm{C}$; c) $4^{\circ} \mathrm{C}$; d) $8^{\circ} \mathrm{C}$; e) $12^{\circ} \mathrm{C}$, f) $16^{\circ} \mathrm{C}$. Two melting peaks at around $63^{\circ} \mathrm{C}$ and $177^{\circ} \mathrm{C}$ corresponded to the melting point $\left(T_{\mathrm{pm}}\right)$ of PCL segment and PLLA segment. 

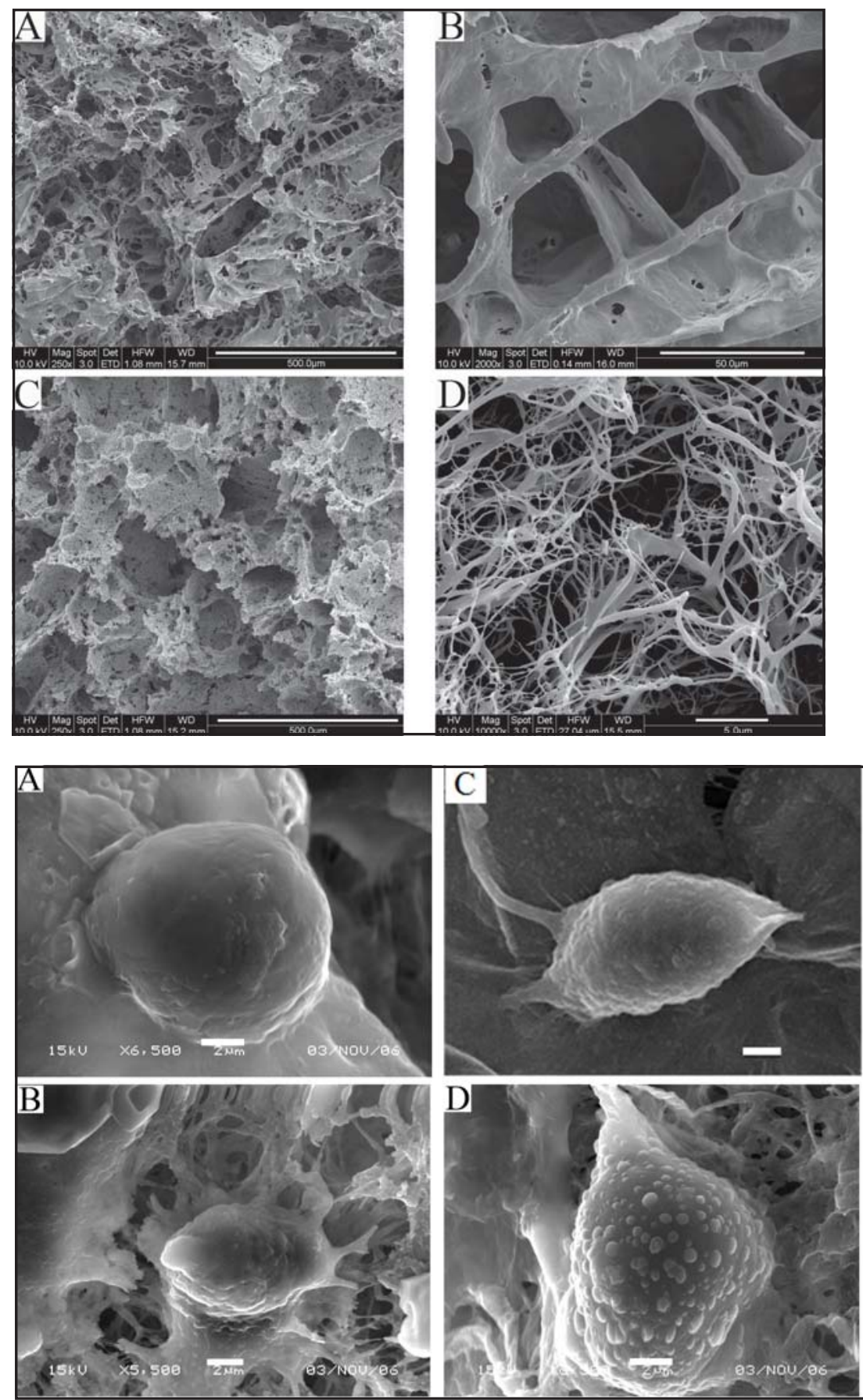

Figure 9. SEM pictures of PCL- $b$ PLLA (50/50) nano-fibrous scaffolds with macroporous structure fabricated from a solution of $5.0 \%(w / v)$ in dioxane (A, B) and THF (C, D). Scale bar in $\mathrm{A}, \mathrm{C}=500 \mu \mathrm{m}$; in $\mathrm{B}=50 \mu \mathrm{m}$ and in $\mathrm{D}=5 \mu \mathrm{m}$.

Figure 10. SEM micrographs of cartilage cells on the PCL- $b$-PLLA (50/50) porous scaffolds with solid wall (A, C, E) and nano-fibrous wall (B, D, F). Cells were cultivated for: (A, B) 12 hours; (C, D) 1 day; (E, F) 6 day. Scale bars for A, B, C, D: $2 \mu \mathrm{m}, \mathrm{E}: 50 \mu \mathrm{m}, \mathrm{F}: 30 \mu \mathrm{m}$.

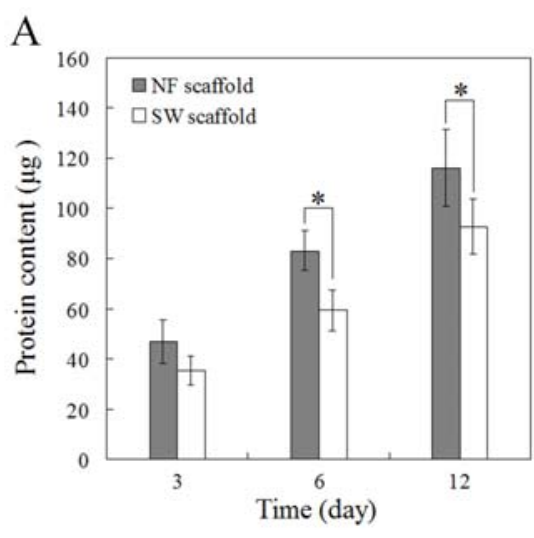

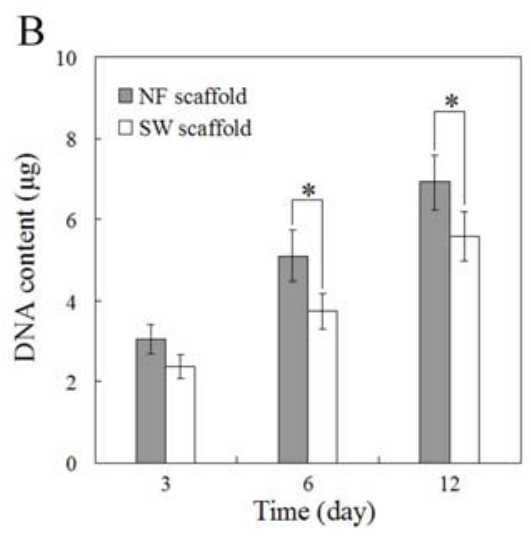
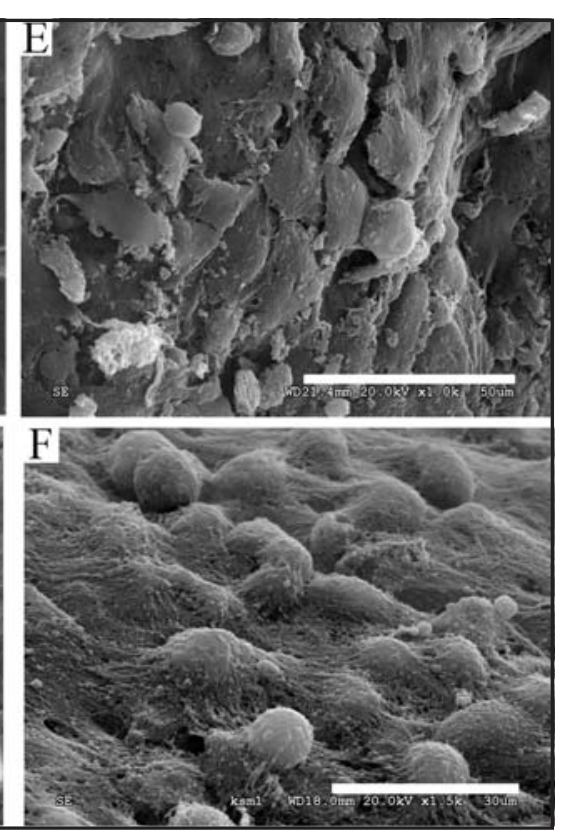

Figure 11. The contents of protein (A) and DNA (B) of the cell cultured on different scaffolds. NF scaffold: nano-fibrous scaffold, SW scaffold: solid-walled scaffold. $p<0.05, \mathrm{n}=7$. 


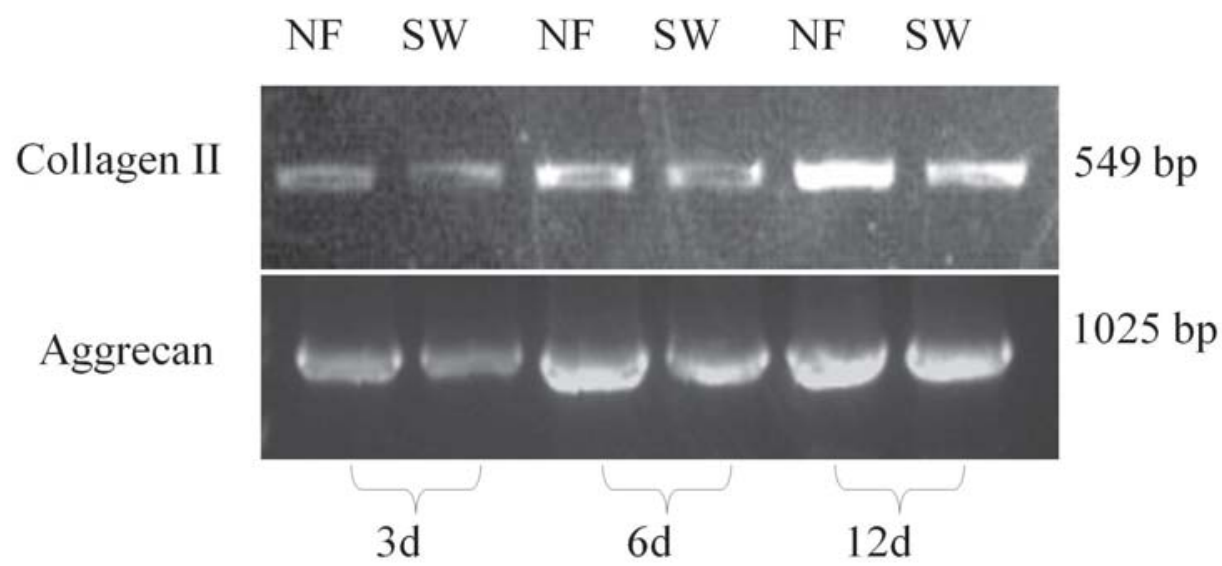

Figure 12. Expression of cartilage-specific genes in NF-scaffold and SW-scaffold chondrocyte cultures for different time analyzed by RT-PCR. The mRNA was analyzed for collagen II and aggrecan which showed bands of 549bp and $1025 \mathrm{bp}$, respectively.

Fig. 3, two single and strong resonance peaks at $\delta=$ $169.7 \mathrm{ppm}$ and $\delta=173.6 \mathrm{ppm}$ were assigned to $\mathrm{C}=\mathrm{O}$ of PLLA and PCL segments, and no resonance peaks were detected between two carbonyl carbon signals. In the FTIR spectrum, two absorption bands were observed at $1757 \mathrm{~cm}^{-1}$ and $1724 \mathrm{~cm}^{-1}$, which corresponded to the stretching vibration of ester carbonyl groups for PCL and PLLA blocks (Fig. 4). Combining ${ }^{13} \mathrm{C}$ NMR with FTIR, both PCL and PLLA sequences were in ordered distribution in macromolecular chain, in addition, there were no occurrences of transesterification to a significant extent under our experimental condition.

\section{Effects of gelation temperature $\left(T_{\text {gel }}\right)$ on the morphologies and crystallization of PCL-b-PLLA scaffolds}

Five characteristic steps were involved in fabricating nanofibrous scaffold by L-L TIPS, including polymer dissolving, gelation, solvent exchanging, freezing and freeze-drying. Among these steps, the gelation process, especially the $T_{\text {gel }}$ was critical in influencing the architecture of the scaffold (Ma and Zhang, 1999; He et al., 2009). Fig. 5 displays the morphologic evolution of PCL- $b$-PLLA scaffolds as a function of $T_{g e l}$. These scaffolds were fabricated from a $5 \%(w / v)$ polymer solution in THF at different $T_{g e l} \mathrm{~s}\left(-40^{\circ} \mathrm{C},-20^{\circ} \mathrm{C}, 4^{\circ} \mathrm{C}, 8^{\circ} \mathrm{C}, 12^{\circ} \mathrm{C}, 16^{\circ} \mathrm{C}\right)$ with aging for $2 \mathrm{~h}$ in the gel status. The nano-fibrous network was observed in all matrixes, but the uniform nano-fibrous network was only obtained at $T_{\text {gel }} \mathrm{s}$ of $-40^{\circ} \mathrm{C}$ and $-20^{\circ} \mathrm{C}$ (Fig. 5A and 5B). The diameters of the nanofibers were $95 \pm 39 \mathrm{~nm}$ and $98 \pm 45 \mathrm{~nm}$, respectively. Increasing $T_{g e l}$ concomitantly tended to generate many knot-like structures (Fig. 5C), coating-like wrapped fibers (Fig. 5D and 5E) and even more continuous smooth pellicles among the nano-fibrous network at $16^{\circ} \mathrm{C}$ (Fig. $5 \mathrm{~F})$. These fibers were thicker than those formed at low $T_{\text {gel }} \mathrm{s}$ of $-40^{\circ} \mathrm{C}$ and $-20^{\circ} \mathrm{C}$ (Fig. 7). Compared with pure PLLA scaffolds, nano-fibrous structures were obtained at relative higher $T_{\text {gel }} \mathrm{s}\left(4 \sim 12^{\circ} \mathrm{C}\right.$, Fig. $\left.6 \mathrm{~A}-6 \mathrm{C}\right)$, with the fiber diameter changing little. However, platelet-like structure (Fig. 6D) was observed instead of smooth pellicle structure as shown in Fig. 5F.
DSC analysis was performed to study the crystallization behaviors of PCL- $b$-PLLA in nano-fibrous scaffolds fabricated at different $T_{\text {gel }} \mathrm{s}$ (Fig. 8). Two melting peaks were observed at around $63^{\circ} \mathrm{C}$ and $177^{\circ} \mathrm{C}$ for all samples, which corresponded to the melting points $\left(T_{\mathrm{pm}}\right)$ of PCL segment and PLLA segment. A little decrease in both $T_{\mathrm{pm}}$ $\left(T_{\mathrm{pm}, \mathrm{PCL}}, T_{\mathrm{pm}, \mathrm{PLLA}}\right)$, compared to homopolymer of PCL and PLLA, meant that the crystallization of PCL and PLLA segments were limited by one another. For PLLA segment, the initial melting temperature $\left(T_{\text {im, PLLA }}\right), T_{\text {pm, PLLA }}$, and the melting enthalpies $\left(\Delta H_{\mathrm{m}, \text { PLLA }}\right)$ changed little within a broad scale of $T_{\text {gel }}\left(-40 \sim 12^{\circ} \mathrm{C}\right)$. Whereas, $\Delta H_{\mathrm{m} \text {, PLLA }}$ increased obviously at the $T_{\text {gel }}$ of $16^{\circ} \mathrm{C}$. In the case of PCL segment, in spite of no obvious decrease in $T_{\mathrm{pm}, \mathrm{PCL}}$ was observed as a function of $T_{\text {gel }}$, a decrease in $T_{\mathrm{im}, \mathrm{PCL}}^{\mathrm{pm}}$, a broad melting range and a definitely decline of $\Delta H_{\mathrm{m}, \mathrm{PCL}}$ were detected.

\section{Properties of porous PCL-b-PLLA scaffolds with different architecture}

For culture of chondrocytes in vitro, the salt-leaching method was incorporated into the phase separation technique to fabricate $3 \mathrm{D}$ scaffolds from PCL- $b$-PLLA. As shown in Fig. 9, large pores in scaffolds were created by leaching out $\mathrm{NH}_{4} \mathrm{HCO}_{3}$ particles, small pores and the texture of the porous wall were determined by the phase separation process, i.e., S-L TIPS or L-L TIPS. In spite of the large pores in the resultant scaffold, the diameter of which was $168 \pm 69 \mu \mathrm{m}$, a ladder-like structure with a solid wall via $\mathrm{S}-\mathrm{L}$ TIPS from a PCL- $b$-PLLA/dioxane/ $\mathrm{NH}_{4} \mathrm{HCO}_{3}$ system (Fig. 9B) was observed. The size of ladder-like pores was measured as $40 \pm 15 \mu \mathrm{m}$. For simplicity, this scaffold was defined as the SW scaffold. Fig. 9D shows the nano-fibrous networks in the large pores wall of the scaffold prepared via L-L TIPS from PCL- $b$-PLLA/THF/ $\mathrm{NH}_{4} \mathrm{HCO}_{3}$ system (defined as NF scaffold), the addition of salt particles did not destroy the nano-fibrous network. However, the diameter of a fiber was about $151 \pm 56 \mathrm{~nm}$, larger than those formed without the incorporation of salt leaching technique (Fig. 5A and 5B).

Though there was no statistical difference between the porosities of these two kinds of scaffolds (Table 3), it was noteworthy that the specific surface and the amount of 
protein adsorbed in NF scaffold were 2.8 and 3.2 times higher than those of the SW scaffold, respectively.

PLLA porous nano-fibrous scaffold prepared by the same process had a higher compression modulus $(218 \pm 34 \mathrm{KPa})$ than PCL- $b$-PLLA SW and NF scaffolds. As PLLA had a similar $M_{\mathrm{n}}$ to that of the PLLA segment in the copolymer, the rigidity of the PCL- $b$-PLLANF scaffold was decreased compared with the PLLA NF scaffold. However, the compression modulus of PCL- $b$-PLLA NF scaffold was still higher than that of the SW scaffold.

\section{Influence of the architecture of PCL-b-PLLA scaffolds on the chondrocyte morphologies and proliferation in vitro}

The morphology of chondrocytes cultured on NF and SW PCL- $b$-PLLA scaffolds were observed by SEM as shown in Fig. 10. In the early period, after $12 \mathrm{~h}$ and $24 \mathrm{~h}$ of culture, chondrocytes cultured in SW scaffolds showed a spherical shape with smooth surface, and then elongated, with few long slender cell processes. In contrast, cells on NF scaffolds assumed a rounded morphology and displayed a rough surface with abundant long slender cell processes or filopodia extensions. Meanwhile, chondrocytes secreted some matrix in the NF scaffolds. After 6 days, chondrocytes flattened and secreted ECM in SW scaffolds. In comparison, cells still maintained a "spherical" condrocyte-like phenotype, and abundant chondral ECM was observed covering the entire surface of the NF scaffold, which was hardly distinguishable from nanofibrous matrix.

In the studies of cell proliferation and biosynthetic activity, chondrocytes were seeded onto both types of scaffolds and cultured up to 12 days. At 3, 6, 12 day intervals, the total protein and DNA contents on the NF scaffolds were 1.3-1.4 times and 1.2-1.4 times higher than those on the SW scaffolds, indicating that the cells proliferated more rapidly on the NF scaffolds than on the SW scaffolds.

\section{Influence of the architecture of PCL-b-PLLA scaffolds on the expression of cartilage-specific ECM genes}

RT-PCR analysis was employed to analyze the mRNA expression of cartilage-specific genes from chondrocyres cultured on the NF scaffold and the SW scaffold up to 12 days (Fig. 12). The expression of collagen II and aggrecan, which were the mRNA expression of cartilage-specific ECM genes, were positively induced in both NF-scaffold culture and SW-scaffold culture, indicating that no dedifferentiation trend of chondrocytes occurred during the culture period. Notably, both collagen II and aggrecan were expressed at a higher level in NF-scaffold culture than in SW-scaffold culture. The differences became more significant at day 12. These results indicated that the NF scaffold could serve as an environment more favorable for maintaining chondrocyte phenotype than the SW scaffold.

\section{Discussion}

Many studies have reported that the transmission of mechanical stimulation signals throughout the scaffolds could effectively promote chondrogenic differentiation and significantly enhance chondral ECM deposition. Biodegradable polymers such as poly(L-lactide-cocaprolactone) (PLCL, 5:5) (Jung et al., 2008), poly(3hydroxy- butyrate-co-3-hydroxyhexanoate) (PHBHHx) (Wang et al., 2008), and poly(1,8-octanediol citrate) (POC) (Kang et al., 2006) have been utilized as scaffold materials for cartilage tissue engineering. One point in common of these materials was their complete rubber-like elasticity. Therefore, the semicrystalline PCL- $b$-PLLA block copolymer was chosen to support chondrocyte growth in our study.

In addition, chondrocytes tend to dedifferentiate, exhibiting profound phenotypic changes while growing in vitro for long periods (Huch et al., 2002; Stokes et al., 2001). Therefore, maintaining a chondrocytic phenotype is indeed challenging. It has been reported that nanoporous or nano-fibrous polymer matrices played a critical role in providing support and anchorage for cells, while maintaining chondrocyte phenotype and enhancing chondrocyte growth and matrix synthesis (Li et al., 2003; Li et al., 2006). The fabrication technologies used for scaffold fabrication in cartilage tissue engineering included electrospinning (Wise et al., 2009), particulate leaching combined with chemical etching (Pattison et al., 2005; Park et al., 2005) and 3-D printing techniques (Yen et al., 2009). L-L TIPS is an easy and effective technique to fabricate 3D nano-fibrous scaffolds (Ma, 2008; Zhang and Ma, 1999). A homogeneous polymer-solvent system would spontaneously undergo a liquid-liquid phase separation when thermodynamically quenched into the unstable zone under the spinodal curve, resulting in a separated polymerrich phase and a polymer-poor phase. Nano-fibrous scaffolds can be obtained when the gelation of the polymer solution system occurs due to the crystallization of polymer-rich phase and solvent removal. Ma et al. have done intensive studies on the fabrication of PLLA NF scaffolds by TIPS and their influence on cell morphology and function in bone tissue engineering (Woo et al., 2003; Hu et al., 2008; Smith et al., 2009; Wei and Ma, 2008). Even now, no one reported the application of PCL- $b$-PLLA scaffold with nano-fibrous structure fabricated by TIPS in cartilage tissue engineering.

Based on the above discussion, the key to fabricate PCL- $b$-PLLA nano-fibrous scaffolds was to choose proper solvents and optimize gelation parameters. On one hand, nano-fibrous structure could result from the crystallization of PCL and PLLA segments independently in the TIPS process at $T_{\text {gel }} \leq$ below $4^{\circ} \mathrm{C}$ using THF as a solvent. On the other hand, the crystallization behavior of these two blocks is confined to each other, especially for the PCL segment at high $T_{\text {gel }}\left(\geq 4^{\circ} \mathrm{C}\right)$. Li et al. reported that the crystallization ability of the PCL segment in the PLLA-PCL-PLLA block copolymer reduced in the presence of PLLA block (Zhao et al., 2007). Combined with the thermal analyses results, it was clear that the knot-like structure and smooth pellicles 
as shown in Fig. 5 indicated the presence of the PCL amorphous phase other than PLLA crystals with plateletlike structure.

We also investigated the L-L TIPS behavior of PCL homopolymer in THF solution. When $T_{\text {gel }} \geq 4^{\circ} \mathrm{C}$, no gelation phenomena were observed in the PCL $\left(M_{\mathrm{n}}: 80 \mathrm{k}\right) / \mathrm{THF}$ system $(5 \%, w / v)$. Zhao et al. (Zhao et al., 2004) also documented that the gelation time of the PCL/THF system was $60 \mathrm{~min}\left(T_{\mathrm{gel}}:-18^{\circ} \mathrm{C}\right)$, longer than the gelation time of the PLLA/THF system at the same $T_{\text {gel }}$, which was $22 \mathrm{~min}$. In this study, we found that increasing $T_{\text {gel }}$ would accelerate molecular movement which would not favor the microphase separation of the PCL domain from the PLLA domain in the PCL- $b$-PLLA/THF system. Thus more PCL molecular chains would be entrapped in the PLLA crystalline regions, which resulted in the decrease in PCL crystallinity. Meanwhile, PLLA crystallization was also interrupted by the PCL domain to some extent. This may explain why there were nanofibers other than the plateletlike structures as in the PLLA/THF system, when the PCLb-PLLA/THF solution gelled at $16^{\circ} \mathrm{C}$.

Although a porous structure can be formed by the L-L TIPS technique, the pore size is quite small for chondrocyte ingrowth as it is mainly determined by the polymer concentration. Moreover, previous studies revealed that a pore size of $100-300 \mu \mathrm{m}$ is essential for chondrocytes to infiltrate (Klompmaker et al., 1992; Klompmaker et al., 1993). Hence, we combined the salt leaching technique with the TIPS method to incorporate macropores into NF and SW scaffolds. The pore size and the interconnection between pores can easily be modulated by controlling the size and quantity of the porogen.

Chondrocyte culture in vitro showed that the cells could infiltrate in the porous scaffolds with both pore morphology types as shown by SEM, implying that the pore size was appropriate for chondrocyte ingrowth. The chondrocyte evaluation based on the morphology, and quantitative assessment such as the total protein and DNA, the semiquantitative comparison of the expression of collagen II and aggrecan mRNA on NF scaffolds and SW scaffolds, indicated that PCL- $b$-PLLA NF scaffolds had the greatest potential in maintaining chondrocyte phenotype and accumulating more cartilage ECM contents. It was because that the nano-fibrous structure mimicked the physical structure of natural ECM, which had a high specific surface area, high protein adsorption capacity and an appropriate mechanical strength.

\section{Conclusions}

In this study, we documented a 3D nano-fibrous scaffold fabricated from PCL- $b$-PLLA (50/50), a semicrystalline diblock copolymer, by L-L TIPS. Uniform networks were created at low gelation temperatures, while high gelation temperatures led to knot-like structures and even continuous smooth pellicles among the nano-fibrous network. Moreover, macroporous structures were created by combining with salt-leaching technique with TIPS. Compared with SW scaffolds, the NF scaffolds had a larger specific surface area, higher protein adsorption capacity and a higher compression modulus. Chondrocytes exhibited a rounded shape, enhanced viability and proliferation on the NF scaffold, compared with the SW scaffold. Further studies are underway to investigate the effects of the scaffold morphology on chondrocyte function as well as the influence of the mechanical stimulation of the PCL- $b$-PLLA nano-fibrous scaffold on chondrocyte function.

\section{Acknowledgements}

The authors would like to acknowledge the financial support by the National Natural Science Foundation of China (grants 50673102 and 30771143).

\section{References}

Brooks PM (2002) Impact of osteoarthritis on individuals and society: how much disability? Social consequences and health economic implications. Curr Opin Rheumatol 14: 573-577.

Buma P, Ramrattan NN, van Tienen TG, Veth RPH (2004) Tissue engineering of the meniscus. Biomaterials 25: 1523-1532.

Cancedda R, Dozin B, Giannoni P, Quarto R (2003) Tissue engineering and cell therapy of cartilage and bone. Matrix Biol 22: 81-91.

Chen GP, Ushida T, Tateishi T (2002) Scaffold design for tissue engineering. Macromol Biosci 2: 67-77.

Chu CR, Coutts RD, Yoshioka M, Harwood FL, Monosov. AZ, Amiei D (1995) Articular cartilage repair using allogeneic perichondrocyte-seeded biodegradable porous polylactic acid (PLA): a tissue-engineering study. J Biomed Mater Res 29: 1147-1154.

Freed LE, Grande DA, Lingbin Z, Emmanual J, Marquis JC, Langer R (1994) Joint resurfacing using allograft chondrocytes and synthetic biodegradable polymer scaffolds. J Biomed Mater Res 28: 891-899.

Gorna K, Gogolewski S (2006) Biodegradable porous polyurethane scaffolds for tissue repair and regeneration. J Biomed Mater Res 79A: 128-138.

Grad S, Zhou L, Gogolewski S, Alini M (2003) Chondrocytes seeded onto poly(1/dl-lactide) $80 \% / 20 \%$ porous scaffolds: a biochemical evaluation. J Biomed Mater Res 66: 571-579.

Grande DA, Breitbart AS, Mason J, Paulino C, Laser J, Schwartz, RE (1999) Cartilage tissue engineering: current limitations and solutions. Clin Orthop 367(Suppl): S176-185.

Guan XP, Quan DP, Shuai XT, Liao KR, Mai KC (2007) Chitosan-graft-poly( $\varepsilon$-caprolactone)s: an optimized chemical approach leading to a controllable structure and enhanced properties. J Polym Sci Part A: Polym Chem 45: 2556-2568.

Gugala Z, Gogolewski S (2000) In vitro growth and activity of primary chondrocytes on a resorbable polylactide three-dimensional scaffold. J Biomed Mater Res 49: 183-191. 
He LM, Zhang YQ, Zeng X, Quan DP, Liao SS, Zeng YS, Lu J, Ramakrishna S (2009) Fabrication and characterization of poly (L-lactic acid) 3D nanofibrous scaffolds with controlled architecture by liquid-liquid phase separation from a ternary polymer-solvent system. Polymer 50: 4128-4138.

Hu J, Liu XH, Ma PX (2008) Induction of osteoblast differentiation phenotype on poly(L-lactic acid) nanofibrous matrix. Biomaterials 29: 3815-3821.

Huch K, Stove J, Puhl W, Gunther KP (2002) Review and comparison of culture-techniques for articular chondrocytes. Z Orthop Ihre Grenzgeb 140: 145-152.

Jeong SI, Kim BS, Lee YM, Ihn KJ, Kim SH, Kim YH (2004) Morphology of Elastic Poly(L-lactide-co- $\varepsilon$ caprolactone) Copolymers and in vitro and in vivo degradation behavior of their scaffolds. Biomacromolecules 5: 1303-1309.

Jung Y, Park MS, Lee JW, Kim YH, Kim SH, Kim SH (2008) Cartilage regeneration with highly-elastic threedimensional scaffolds prepared from biodegradable poly(L-lactide-co- $\varepsilon$-caprolactone). Biomaterials 29: 46304636.

Kang Y, Yang J, Khan S, Anissian L, Ameer GA (2006) A novel biodegradable elastomers for cartilage tissue engineering. J Biomed Mater Res 77A: 331-339.

Kim JK, Park DJ, Lee MS, Ihn KJ (2001) Synthesis and crystallization behavior of poly(L-lactide)-blockpoly(E-caprolactone) copolymer. Polymer 42: 7429-7441.

Kister G, Cassanas A, Bergounhon A, Hoarau D, Vert M (2000) Structural characterization and hydrolytic degradation of solid copolymers of D,L-lactide-co- $\varepsilon$ caprolactone by raman spectroscopy. Polymer 41: 925932.

Klompmaker J, Jansen HW, Veth RP, Nielsen HK, de Groot JH, Pennings AJ (1993) Porous implants for knee joint meniscus reconstruction: a preliminary study on the role of pore sizes in ingrowth and differentiation of fibrocartilage. Clin Mater 14: 1-11.

Klompmaker J, Jansen HW, Veth RP, Nielsen HK, de Groot JH, Pennings AJ, Kuijer R (1992) Meniscal repair by fibrocartilage? An experimental study in the dog. J Orthop Res 10: 359-370.

Laurencin CT, Ambrosio AMA, Borden MD, Cooper JA (1999) Tissue engineering: orthopedic applications. Annu Rev Biomed Eng 1: 19-46.

Li SM, Espartero JL, Foch P, Vert M (1996) Structural characterization and hydrolytic degradation of a $\mathrm{Zn}$ metal initiated copolymer of L-lactide and $\varepsilon$-caprolactone. J Biomater Sci Polymer Edn 8: 165-186.

Li WJ, Danielson KG, Alexander PG, Tuan RS (2003) Biological response of chondrocytes cultured in threedimensional nanofibrous poly( $\varepsilon$-caprolactone) scaffolds. J Biomed Mater Res 67A: 1105-1114.

Li WJ, Jiang YJ, Tuan RS (2006) Chondrocyte phenotype in engineered fibrous matrix is regulated by fiber size. Tissue Eng 12: 1775-1785.

Ma PX (2008) Biomimetic materials for tissue engineering. Adv Drug Delivery Rev 60: 184-198.

Ma PX, Zhang RY (1999) Synthetic nano-scale fibrous extracellular matrix. J Biomed Mater Res 46: 60-72.
Nair LS, Cato LT (2007) Biodegradable polymers as biomaterials. Prog Polym Sci 32: 762-798.

Ochi M, Uchio Y, Tobita M, Kuriwaka M (2001) Current concepts in tissue engineering technique for repair of cartilage defect. Artif Organs 25: 172-179.

Park GE, Pattison MA, Park K, Webster TJ (2005) Accelerated chondrocyte functions on $\mathrm{NaOH}$-treated PLGA scaffolds. Biomaterials 26: 3075-3082.

Pattison MA, Wurster S, Webstera TJ, Haberstroh KM (2005) Three-dimensional, nano-structured PLGA scaffolds for bladder tissue replacement applications. Biomaterials 26: 2491-2500.

Sellards RA, Nho SJ, Cole BJ (2002) Chondral injuries. Curr Opin Rheumatol 14: 134-141.

Smith LA, Liu XH, Hu J, Ma PX (2009) The influence of three-dimensional nanofibrous scaffolds on the osteogenic differentiation of embryonic stem cells. Biomaterials 30: 2516-2522.

Solchaga LA, Goldberg VM, Caplan AI (2001) Cartilage regeneration using principles of tissue engineering. Clin Orthop 391(Suppl): S161-170.

Stoddart MJ, Grad S, Eglin D, Alini M (2009) Cells and biomaterials in cartilage tissue engineering. Regenerative Medicine 4: 81-98.

Stokes DG, Liu G, Dharmavaram R, Piera-Velazquez S, Jimenez SA (2001) Regulation of type-II collagen gene expression during human chondrocyte de-differentiation and recovery of chondrocyte-specific phenotype in culture involves Sry-type high-mobility-group box (SOX) transcription factors. Biochem J 360: 461-470.

Tuli R, Li WJ, Tuan RS (2003) Current state of cartilage tissue engineering. Arthritis Res Ther 5: 235-238.

Wang Y, Bian YZ, Wu Q, Chen GQ (2008) Evaluation of three-dimensional scaffolds prepared from poly(3hydroxybutyrateco-3-hydroxyhexanoate) for growth of allogeneic chondrocytes for cartilage repair in rabbits. Biomaterials 29: 2858-2868.

Wei GB, Ma PX (2008) Nanostructured biomaterials for Regeneration. Adv Funct Mater 18: 3568-3582.

Wise JK, Yarin AL, Megaridis CM, Cho M (2009) Chondrogenic differentiation of human mesenchymal stem cells on oriented nanofibrous scaffolds: engineering the superficial zone of articular cartilage. Tissue Eng: Part A 15: 913-21.

Woo KM, Chen VJ, Ma PX (2003) Nano-fibrous scaffolding architecture selectively enhances protein adsorption contributing to cell attachment. J Biomed Mater Res 67A: 531-537.

Yen HJ, Hsu SH, Tseng CS, Huang JP, Tsai CL (2009) Fabrication of precision scaffolds using liquid-frozen deposition manufacturing for cartilage tissue engineering. Tissue Eng: Part A 15: 965-975.

Zhao J, Yuan XY, Cui YL, Ge QB, Yao KD (2004) Preparation and characterization of poly(L-lactide)/poly(ecaprolactone) fibrous scaffolds for cartilage tissue engineering. J Appl Polym Sci 91: 1676-1684.

Zhao ZX, Yang L, Hu YF, He Y, Wei J, Li SM (2007) Enzymatic degradation of block copolymers obtained by sequential ring opening polymerization of L-lactide and ع-caprolactone. Polym Degrad Stab 92: 1769-1777. 